\title{
Evidence on EVA ${ }^{\circledR}$
}

\section{Gary C. Biddle, ${ }^{\text {a,b }}$ Robert M. Bowen, ${ }^{\text {a }}$ James S. Wallace}

\begin{abstract}
Economic Value Added $\left(\mathrm{EVA}^{\circledR}\right)$ has attracted considerable attention as an alternative to traditional accounting earnings for use in both valuation and incentive compensation. With a host of consultants now marketing related metrics, numerous claims have been made - most based on anecdotal evidence or in-house studies. This paper summarizes independent evidence regarding EVA's alleged advantages.

We begin by reviewing the theory that links the underlying concept of residual income to shareholder value. Second, we discuss how Stern Stewart modifies residual income to produce its proprietary EVA metric and show how median EVA compares with residual income, net income and operating cash flows over the period 1988-97. Third, we examine the claim that EVA is more closely associated with stock returns and firm value than is net income. The evidence indicates that EVA does not dominate net income in associations with stock returns and firm values. Fourth, we examine a second claim that compensation plans based on residual income motivate managers to take actions consistent with increasing shareholder value. Here, the independent evidence suggests that managers do respond to residual income-based incentives. Finally, we discuss how a metric such as EVA can be useful for internal incentive purposes even if it conveys little news to market participants regarding the firm's valuation.

${ }^{a}$ University of Washington Business School, Seattle, WA 98195-3200, USA

${ }^{b}$ School of Business and Management, Hong Kong University of Science \& Technology, Clear Water Bay, Kowloon, Hong Kong, China

${ }^{c}$ Graduate School of Management, University of California, Irvine, CA 92697-3125, USA
\end{abstract}

The comments of Robert Higgins, Jane Kennedy, Jennifer Koski, Suil Pae, Terry Shevlin, and seminar participants at Hong Kong University of Science \& Technology are greatly appreciated. 


\section{Evidence on EVA ${ }^{\circledR}$}

$\mathrm{EVA}^{\circledR}$, an acronym for economic value added, is the registered tradename of Stern Stewart \& Company for their version of a long-known and compelling concept called residual income. Hailed by Fortune as the "New Key to Creating Wealth" and “Today's Hottest Financial Product," EVA has attracted considerable attention as a valuation and incentive tool. With a host of consultants now marketing related metrics, numerous claims have been made - most based on anecdotal evidence or in-house studies. However, little independent evidence has existed until recently regarding EVA's alleged advantages. This article helps fill this void by presenting results from recent academic research.

We first review briefly the theory that links residual income to shareholder value. We then discuss how Stern Stewart modifies residual income to produce its proprietary EVA and show how it compares with residual income, earnings and operating cash flows over the period 198897. Next we examine evidence regarding the claim that EVA has a stronger association with stock prices and firm values than traditional accounting measures. We then examine a second claim that residual income based compensation plans motivate managers to take actions consistent with increasing shareholder value. Finally, we discuss and integrate recent findings on the usefulness of residual income metrics in valuation and incentive compensation.

\section{THE THEORY}

EVA is the leading example of a new class of metrics that attempt to measure an underlying concept called residual income. Recognized by economists since the 1770 s, residual income is based on the premise that, in order for a firm to create wealth for its owners, it must 
earn more on its total invested capital than the cost of that capital. ${ }^{1}$ Whereas traditional

accounting net income measures 'profits' net of interest expense on debt capital, residual income measures 'profits' net of the full cost of both debt and equity capital.

To compute residual income, begin with net operating profits after tax (NOPAT) and subtract the total cost of capital measured as the weighted-average cost of capital (WACC) times the total invested capital (CAPITAL). ${ }^{2}$ Notationally, residual income (RI) for period $t$ is:

$$
\text { Residual Income }_{\mathrm{t}}\left(\mathrm{RI}_{\mathrm{t}}\right)=\text { NOPAT }_{\mathrm{t}}-\left[\mathrm{WACC}_{\mathrm{t}} \times \mathrm{CAPITAL}_{\mathrm{t}-1}\right]
$$

Since NOPAT can alternatively be expressed as a rate of return on invested capital (i.e., return on assets, ROA) times capital, residual income can be restated as in (1b). Expression (1b) is intuitively appealing because it separates total return on capital from the total cost of capital:

$$
\mathrm{RI}_{\mathrm{t}}
$$

$$
=\left[\text { ROA }_{t} \times \text { CAPITAL }_{t-1}\right]-\left[\text { WACC }_{t} \times \text { CAPITAL }_{t-1}\right]
$$

Regrouping the right hand side terms of (1b), we observe in (1c) that firms producing positive residual income earn a positive 'spread' between the percent return on invested capital and the percent cost of capital:

\footnotetext{
${ }^{1}$ See R. Hamilton, An Introduction to Merchandize, Edinburgh (1777), and A. Marshall, Principles of Economics, MacMillan Press Ltd., London, New York (1890). Coined residual income by General Electric in the 1950s, this concept also has been labeled as excess earnings by J. Canning, The Economics of Accountancy, Ronald Press, New York (1929) and G. Preinreich, "The Law of Goodwill," Accounting Review, Vol. 12 (1936), 317-329, G. Preinreich, "Goodwill in Accountancy," Journal of Accountancy (July, 1937), 28-50, G. Preinreich, "Annual Survey of Economic Theory: The Theory of Depreciation," Econometrica (January 1938), 219-231; super-profits by H. Edey, "Business Valuation, Goodwill and the Super-profit Method," Accountancy, (January/February, 1957); excess realizable profit by E. Edwards and P. Bell, The Theory and Measurement of Business Income, University of California Press, Berkeley (1961); excess income by J. Kay, "Accountants, too, Could Be Happy in a Golden Age: The Accountant's Rate of Profit and the Internal Rate of Return," Oxford Economic Papers, Vol. 28 (1976), $447-$ 460; and abnormal earnings by K. Peasnell, "On Capital Budgeting and Income Measurement" Abacus, Vol. 17 (1981), 52-67, K. Peasnell, "Some Formal Connection Between Economic Values and Yields and Accounting Numbers," Journal of Business Finance and Accounting, Vol. 9 (1982), 361-381 and G. Feltham and J. Ohlson, "Valuation and Clean Surplus Accounting for Operating and Financing Activities," Contemporary Accounting Research, Vol. 11 (1995), 689-731.

${ }^{2}$ Capital is generally defined to be assets (net of accumulated depreciation and amortization) invested in goingconcern operating activities, or equivalently, contributed and retained debt and equity capital at the beginning of the period (net of non-operating capital). Non-interest bearing debt capital (e.g., accounts payable) is sometimes subtracted from total capital under the argument that it does not require a return.
} 
(1c) $\mathrm{RI}_{\mathrm{t}}$

$$
=\left[\mathrm{ROA}_{\mathrm{t}}-\mathrm{WACC}_{\mathrm{t}}\right] \times \text { CAPITAL }_{\mathrm{t}-1}
$$

Put still another way, residual income can be seen in (1d) to equal traditional accounting net income (NI) minus a charge for the cost of equity capital, where the cost of equity capital can be expressed as the beginning-of-period book value of equity (BV) times the cost of equity capital (k). That is,

$$
=\mathrm{NI}_{\mathrm{t}}-\left[\mathrm{k}_{\mathrm{t}} \times \mathrm{BV}_{\mathrm{t}-1}\right]
$$

A look at the right hand sides of expressions (1a) to (1d) suggests that there are three main opportunities to increase residual income. Other things equal, managers will increase residual income to the extent they increase NOPAT and ROA, decrease WACC (though this is inherently more difficult), or reallocate capital away from negative 'spread' toward positive 'spread' investments. These opportunities become incentives when managers are evaluated or compensated based on residual income (or EVA). Later in this article we review evidence on the effects of these incentives on managements' actions.

To see more clearly how residual income relates to shareholder wealth, consider the familiar discounted dividend model of equity valuation, where the market value of equity, $\mathrm{V}_{\mathrm{t}}$, is expressed as the net present value of future dividends:

$$
V_{t}=\sum_{\tau=1}^{\tau=\infty} \frac{D_{t+\tau}}{(1+k)^{\tau}}
$$

This expression can be restated using the so-called 'clean surplus substitution,' where clean surplus is the accounting convention that the accounting book value of equity (also called surplus) is changed only by earnings and dividends: ${ }^{3}$

\footnotetext{
${ }^{3}$ See, for example, Peasnell (1982), cited above; Ohlson (1995), cited above; Feltham and Ohlson (1995), cited above; and J. O'Hanlon and K. Peasnell, "Wall Street's Contribution to Management Accounting: The Stern Stewart EVA Financial Management System," Management Accounting Research, Vol. 9, No. 4 (1998), $421-444$. Clean surplus generally holds under u.s. accounting principles, with limited exceptions such as foreign currency translation gains and losses. Additional exceptions arise in the accounting principles of other countries.
} 


$$
\mathrm{BV}_{\mathrm{t}}=\mathrm{BV}_{\mathrm{t}-1}+\mathrm{NI}_{\mathrm{t}}-\mathrm{D}_{\mathrm{t}}
$$

where $\mathrm{D}_{\mathrm{t}}$ is the net "dividends" paid to owners for period t (i.e., cash dividends plus share repurchases net of capital contributions). Solving equation (1d) for $\mathrm{NI}_{t}$, equation (3) for $\mathrm{D}_{\mathrm{t}}$, and substituting into the discounted dividends model (2), equity value can be expressed in terms of discounted residual income and equity book values (4a):

(4a) $\quad V_{t}=\sum_{\tau=1}^{\tau=\infty} \frac{R I_{t+\tau}+(1+k) B V_{t+\tau-1}-B V_{t+\tau}}{(1+k)^{\tau}}$

Further assuming that $\mathrm{BV}_{\mathrm{t}+\tau} /(1+\mathrm{k})^{\tau}$ approaches 0 as $\tau$ approaches $\infty$, equity value can be expressed solely in terms of beginning book equity and discounted residual income: ${ }^{4}$

$$
V_{t}=B V_{t}+\sum_{\tau=1}^{\tau=\infty} \frac{R I_{t+\tau}}{(1+k)^{\tau}}
$$

Because this relationship with equity value described in (4b) holds for residual income but not for accounting earnings (because accounting earnings does not include a charge for equity capital), one might expect that residual income should therefore be superior to accounting earnings in explaining firm values and stock returns. As we shall see, a key problem with this inference is that stock market participants only have past and current data available to estimate the model's unobservable future residual income. Thus the empirical question becomes: which measure conveys more information about future residual income - current residual income or current earnings? It could be that other metrics better reveal this future than do past and current

\footnotetext{
${ }^{4}$ EVA (discussed below) can be substituted for residual income without loss of equivalence. When applying (4b), analysts truncate the infinite series and attempt to capture residual income beyond the forecast horizon in a 'terminal value' term.
} 
observations of residual income (or EVA). ${ }^{5}$ Before presenting evidence on this issue, we first describe Stern Stewart's version of residual income called EVA.

\section{$\mathbf{E V A}^{\circledR}$}

First introduced in the late 1980s, Stern Stewart's EVA has generated considerable publicity and over 300 client adoptions to date, including major international corporations such as Coca-Cola, Eli Lilly, and Siemens. ${ }^{6}$ EVA also has attracted competitors who offer related or competing metrics. The resulting intense competition has been referred to as "metric wars" in the financial press. ${ }^{7}$

[insert figure 1 about here]

Figure 1 summarizes the steps that transform underlying cash flows from operations (CFO) into Stern Stewart's economic value added (EVA). Adjusting CFO for accounting accruals (such as depreciation and interest expense) yields bottom line accounting earnings (NI). Adding back after-tax interest expense to NI yields net operating profits after tax (NOPAT). Subtracting the current cost of both debt and equity capital from NOPAT yields residual income (RI). To compute economic value added (EVA), Stern Stewart adjusts the NOPAT and capital

\footnotetext{
${ }^{5}$ Similar reasoning explains why earnings have been found to better explain stock returns and firm values than cash flows, even though firm values can alternatively be modeled in discounted (free) cash flows (see, e.g., Gary C. Biddle, Gim S. Seow and Andrew F. Siegel, "Relative versus Incremental Information Content," Contemporary Accounting Research (Fall 1995), 1-23).

${ }^{6}$ Stern Stewart also advocates a second performance metric based on (4b). Subtracting $\mathrm{BV}_{\mathrm{t}}$ from both sides yields "market value added" (MVA), a measure of the equity value created by management beyond contributed equity capital, expressed in terms of discounted expected residual income:$$
M V A_{t}=V_{t}-B V_{t}=\sum_{\tau=1}^{\tau=\infty} \frac{R I_{t+\tau}}{(1+k)^{\tau}} . \text { A "Performance 1000" ranking based on MVA has appeared }
$$

annually in Fortune since 1993.

${ }^{7}$ R. Myers, "Metric Wars," CFO, Vol. 12 (October 1996), 41-50. Performance measures marketed by competing firms include cash-flow return on investment (CFROI) by HOLT Value Associates, total business return (TBR) by Boston Consulting Group, shareholder value added (SVA) by LEK/Alcar, discounted economic profits (EP) by Marakon Associates, and economic value management (EVM) by KPMG. See also Christopher D. Ittner and
} 
components of residual income for what are termed "accounting anomalies" or "distortions". 8

Some of their more common adjustments are shown in Table 1. Some of these adjustments undo traditional accounting accruals (such as eliminating deferred tax accounting in favor of actual cash taxes paid). Other adjustments switch accrual methods (e.g. from LIFO to FIFO). Still others introduce new accruals not used in traditional GAAP-based accounting (e.g., capitalization and amortization of marketing and $\mathrm{R} \& \mathrm{D}$ expenditures).

Stern Stewart argues that these EVA adjustments produce a better measure of residual income that enhances comparability and also corrects distortions of managerial incentives introduced by standard GAAP accounting. ${ }^{9}$ For example, certain adjustments remove or reduce managers' discretion in computing EVA (e.g., the opportunity to influence bad debt accruals). Others adjustments reduce incentives to make operating, investing and financing choices that boost earnings and EVA in the short term, but reduce shareholder wealth. Examples of such myopic decision-making include cutbacks in positive-NPV capital investments, marketing and R\&D expenditures. ${ }^{10}$ These adjustments are particularly relevant when executive pay is closely linked to EVA - a situation that can produce incentives for short-term 'gaming.' Other mechanisms used in conjunction with EVA to help control 'short-termism' include bonus banks and EVA-based stock option plans.

[insert table 1 about here]

David F. Larcker, "Innovations in Performance Measurement: Trends and Research Implications" Journal of Management Accounting Research, Vol. 10 (1998), 205-238.

${ }^{8}$ Stern Stewart has developed over 160 proprietary adjustments to NOPAT and CAPITAL (although generally only a few are employed in each client application).

${ }^{9}$ They also undoubtedly increase marketing effectiveness by creating a proprietary measure available only from Stern Stewart.

${ }^{10}$ See, for example, Stephen F. O’Byrne, "Does Value Based Management Discourage Investment in Intangibles?, Working paper, Shareholder Value Advisors (1999). 
Figure 2 plots median values of four alternative performance measures - net income (NI), residual income (RI), EVA, and cash flow from operations (CFO) - over the period 198897. ${ }^{11}$ Since accounting accruals generally reduce net income (e.g., due to depreciation and amortization expense), it is not surprising that median NI plots well below median CFO in each year. EVA and RI lie well below NI because of the incremental charge for equity capital. However, the difference between EVA and RI is relatively small, suggesting that the net effect of Stern Stewart's accounting adjustments is not large on average. ${ }^{12}$ Interestingly, despite the sample being drawn from among the largest firms in the U.S. economy, median EVA is negative until 1995 and median RI is negative for every year. Near zero EVA and RI is consistent with a competitive economy in which even the typical large firm has difficulty earning more than its cost of capital. Low values of EVA and RI also are consistent with a potential upward bias in Stern Stewart's cost of capital estimates (also used here for computing RI).

[insert figure 2 about here]

\section{CLAIM \#1 - EVA BETTER EXPLAINS STOCK RETURNS AND FIRM VALUES}

Proponents of EVA and other residual income measures have made two primary claims about EVA and/or residual income: 1) they better explain stock returns and firm values than traditional GAAP-based accounting metrics, and 2) they better motivate managers to create shareholder wealth. In this section and the next, we examine recent independent evidence regarding each claim.

\footnotetext{
${ }^{11}$ The data are from Stern Stewart's publicly available database and the Standard \& Poors COMPUSTAT database. The Stern Stewart data are summarized in Fortune's annual Performance 1000 issue.

${ }^{12}$ For example, in any period, current R\&D costs can be approximately equal to the amortization of past capitalized costs. And even if, say, capitalized R\&D costs are large and growing, any expense reduction due to capitalization will be offset by higher cost of capital charges due to capitalized R\&D in the capital base.
} 


\section{Evidence on Associations with Stock Returns and Firm Values}

In our recently published article entitled "Does EVA Beat Earnings? Evidence on

Associations with Stock Returns and Firm Values", ${ }^{13}$ we provide evidence on the first claim by examining whether EVA and residual income (RI) are more closely associated with stock returns and firm values than two currently mandated performance metrics - net income (measured as earnings before extraordinary items) and cash flow from operations. ${ }^{14}$ Specifically, we examine three related questions, the first of which is:

Q1: Does EVA and/or RI dominate earnings (NI) and operating cash flow (CFO) in explaining contemporaneous annual stock returns?

We examine a sample of 6,174 firm-years over the period 1984-1993. As a test of association (goodness of fit) we use adjusted R-squared (Adj. $\mathrm{R}^{2}$ ) from a regression of stock market returns on each performance metric. ${ }^{15}$ Our results, summarized in Figure 3, indicate that current period accounting earnings (NI) is significantly more highly associated with market-adjusted annual stock returns $\left(\right.$ Adj. $\left.\mathrm{R}^{2}=13 \%\right)$ than are $\mathrm{RI}\left(\right.$ Adj. $\left.\mathrm{R}^{2}=7 \%\right)$ and EVA (Adj. $\left.\mathrm{R}^{2}=6 \%\right)$, and that all three dominate cash flows from operations, $\mathrm{CFO}\left(\right.$ Adj. $\left.\mathrm{R}^{2}=3 \%\right) .{ }^{16}$ This finding is supported across a number of alternative specifications. These results do not support the claim that EVA

\footnotetext{
${ }^{13}$ Gary C. Biddle, Robert M. Bowen and James S. Wallace, "Does EVA ${ }^{\circledR}$ Beat Earnings? Evidence on Associations with Stock Returns and Firm Values," Journal of Accounting and Economics, Vol. 24, No. 3 (December 1997), 301-336.

${ }^{14}$ For examples of such claims, see G. Bennett Stewart, The Quest For Value, Harper Business, New York (1991), pgs. 2, and 66; Harvard Business Review (November-December, 1995), p. 20; and G. Bennett Stewart, "Eva: Fact or Fantasy," Journal of Applied Corporate Finance Vol. 7, No. 2 (Summer 1994), p. 75.

${ }^{15}$ See Biddle, Bowen and Wallace (1997), cited above, equation (6), Figure 3 and related text for elaboration on this regression and related statistical tests.

${ }^{16}$ The strength of the relation between stock returns and contemporaneous performance is a function of the length of the time frame or 'window' over which returns and performance are measured. For example, Adj. $\mathrm{R}^{2}$ for regressions over 5-year windows were NI (31\%), CFO (19\%), EVA (14\%) and RI (11\%). Again, we find no evidence of EVA or RI 'beating' earnings over five-year intervals.
} 
dominates earnings in its association with stock returns. On the contrary, NI appears to outperform EVA on average.

[Insert Figure 3 about here]

A second and related question that we examine is whether EVA and/or RI complement currently mandated performance measures by conveying information beyond that contained in contemporaneous NI and CFO:

Q2: Do components unique to EVA and/or RI help explain contemporaneous stock returns beyond that explained by $\mathrm{CFO}$ and $\mathrm{NI}$ ?

To address this question, we decompose EVA into its component parts as shown in Figure 1 (e.g., cash from operations, operating accruals, capital charge, and net accounting 'adjustments') and evaluate the contribution of each component toward explaining contemporaneous stock returns. We find that EVA components add little to the explanatory power of the regressions. Further, tests across alternative specifications indicate that, while traditional earnings components such as operating cash flow and accruals are consistently significant, components unique to EVA-that is, the capital charge and accounting adjustments - are often not significant in explaining contemporaneous returns. These results suggest that EVA components contribute only marginally to the information already available to market participants in net income.

Figure 4 summarizes our overall findings on the value-relevance of EVA versus the other performance measures. It combines comparisons of relative information content comparisons (Adj. $\mathrm{R}^{2} \mathrm{~s}$ ) from question 1 (which are shown as circle sizes in the figure), and comparisons of incremental information content comparisons (F-statistics) from question 2, shown as relative positioning or lack of overlap (with less overlap indicating more incremental 
information content). Overall, neither EVA nor RI appears to dominate NI in its association with stock market returns. NI has the largest relative information content (as indicated by the largest circle) and the overlap between circles is large suggesting that there is little incremental information content in EVA, RI and CFO beyond that contained in NI.

\section{[Insert Figure 4 here]}

We also examine a related claim that EVA is more highly associated with firm values (versus stock returns considered above):

Q3: Does EVA dominate earnings in explaining firm values?

To address this question, we replicate and extend a study authored by former Stern Stewart vicepresident Stephen O'Byrne that appeared in the Spring 1996 issue of this journal. ${ }^{17}$ O'Byrne first compares Adj. $\mathrm{R}^{2}$ s from regressing firm value on EVA and earnings measured as NOPAT. He reports an Adj. $\mathrm{R}^{2}$ of $31 \%$ for the EVA regression and $33 \%$ for the NOPAT regression. Next, he adjusts the EVA regression by: 1) allowing separate coefficients for positive and negative values of EVA, 2) including the natural log of capital in an attempt to capture differences in the way the market values firms of different sizes, and 3) including 57 industry dummy variables in order to capture potential industry effects. When all of these adjustments are included, O'Byrne obtains a larger Adj. $\mathrm{R}^{2}$ for the enhanced EVA regression (56\%) than for NOPAT (33\%).

However, notice that O'Byrne makes 'adjustments' only to the EVA regression. When we 'level the playing field' by applying the same adjustments to the NOPAT regression and also examine NI, EVA's superiority disappears. The NI regression has a significantly higher association with firm value $\left(\mathrm{Adj} . \mathrm{R}^{2}=53 \%\right.$ ) than the EVA regression (Adj. $\mathrm{R}^{2}=50 \%$ ) and the NOPAT regression (Adj. $\mathrm{R}^{2}=49 \%$ ). The latter two are statistically indistinguishable. Thus, as 
with our stock returns tests, these results do not support the contention that EVA outperforms earnings in explaining firm values. To the contrary, and in contrast to claims by Stern Stewart, our evidence suggests that earnings more often dominates EVA in value-relevance to market participants. $^{18}$

\section{Why don't residual income and EVA "beat" earnings?}

There are several potential explanations as to why RI and EVA do not dominate earnings in associations with stock returns and firm values. First, recall that the valuation model in equation (4b) is specified in terms of discounted future RI (or EVA) - not on past and current realizations. In this light, our evidence suggests that realized earnings are a better predictor of future EVA than realized EVA itself. ${ }^{19}$ Also recall that the key difference between NI and RI is the cost of equity capital, and that the key difference between RI and EVA are Stern Stewart's accounting adjustments (such as the capitalization of R\&D). Earnings could dominate RI if market participants use cost of capital estimates different than those provided by Stern Stewart.

Earnings could dominate EVA if Stern Stewart's accounting adjustments have the effect of “undoing' discretionary accruals that market participants use to infer firms' future prospects. Alternatively, the market may make a set of accounting adjustments different from those applied by Stern Stewart. Even if the market adjustments are similar to Stern Stewart's, they may

\footnotetext{
${ }^{17}$ Stephen F. O’Byrne, "EVA ${ }^{\circledR}$ and Market Value," Journal of Applied Corporate Finance, Vol. 9, No. 1, 116-125.

${ }^{18}$ Other independent studies report similar findings. See S. Chen and J. Dodd, "Economic Valued Added EVA ${ }^{\circledR}$ : An Empirical Examination of a New Corporate Performance Measure," Journal of Managerial Issues (Fall 1997): 318-333; S. Chen and J. Dodd, "Usefulness of Accounting Earnings, Residual Income, and EVA: A Valuerelevance Perspective," working paper, Clarion University (1997); Pamela P. Peterson and David R. Peterson, "Company Performance and Measures of Value Added," The Research Foundation of the Institute of Chartered Financial Analysts (1996), Chapter 4; and R. Bernstein, Quantitative Viewpoint an Analysis of EVA - Part II, Merrill Lynch \& Co. Global Securities \& Economics Group, Quantitative \& Equity Derivative Research Department (February 1998).

${ }^{19}$ Realized earnings are similarly more predictive of future free cash flows than are cash flow themselves. This is not surprising since earnings smooth irregular cash flow realizations and accruals allow managers to convey to market participants inferences regarding their firms' future prospects.
} 
contain little news. If earnings already conveys essential economic news (e.g., unexpected revenues and costs) - and the market provides its own cost of capital estimate - there may be little left to glean from EVA and RI. It also is possible that, for the time period we studied, the market had yet to recognize valuable incremental information contained in EVA and RI numbers.

\section{CLAIM \#2 - EVA BETTER MOTIVATES MANAGERS TO INCREASE SHAREHOLDER WEALTH}

A second principal claim is that residual income-based incentive schemes are better than earnings-based plans in motivating managers to create shareholder wealth. ${ }^{20}$ For example, Stern Stewart advertisements often include testimonials and charts showing rising EVA and share prices. They convey the impression that EVA adoption is responsible for increasing shareholder wealth by better aligning internal management incentives with owners' interests. ${ }^{21}$ Because it can be shown that discounted future RI is equivalent to discounted future cash flows in a capital budgeting decision, ${ }^{22}$ RI-based incentives are claimed to better motivate managers to select positive net-present-value investments than traditional accounting metrics. As we noted earlier, both RI and EVA-based compensation should reward managers for increasing operating profits (NOPAT) and return on invested capital (ROA), reducing the weighted average cost of capital (WACC), and reallocating capital from negative spread (ROA - WACC) activities toward positive spread activities. We next present evidence on whether managers actually respond to these incentives at firms that adopt residual income-based metrics. $^{23}$

\footnotetext{
${ }^{20}$ For example, see G. Bennett Stewart (1991), cited above.

${ }^{21}$ Of course, some EVA adopters have prospered (e.g., Coca-Cola and Eli Lilly), others have not fared well (e.g., Quaker Oats) and others have dropped or de-emphasized EVA (e.g., AT\&T, Monsanto).

${ }^{22}$ For example, see Robert M. Bowen and James S. Wallace, "Interior Systems" case, Issues in Accounting Education (1999), forthcoming.

${ }^{23}$ Another Stern Stewart claim is that EVA is applicable to virtually any type of firm. Although residual income type measures like EVA are indeed widely applicable, they are, like earnings, inherently backward looking. As a result, earnings-based metrics (including EVA) can be more difficult to implement as a management incentive tool
} 


\section{Evidence on Incentives and Performance}

In a recently published paper entitled “Adopting Residual Income-Based Performance

Plans: Do You Get What You Pay For?", ${ }^{24}$ Wallace provides independent evidence on this second set of claims. Specifically, he examines what amounts to a precondition for the possibility that managers of firms adopting RI-based plans (including EVA) create wealth for their shareholders: namely, that they change their operating, investing and financing decisions in response to RI incentives. Evidence consistent with this precondition does not prove that RI (or EVA) creates shareholder wealth, but it provides a necessary first step by demonstrating that RI-based incentive compensation plans are effective in altering management decisions.

For each of the four research questions listed below, forty firms that adopted residual income-based compensation plans were compared with forty matched-pair control firms that continued to use traditional compensation schemes. Results are summarized in Figure 5, where "\% relative change" indicates average percentage changes in selected actions of firms that adopt residual income-based incentives relative to the non-adopters.

[Insert Figure 5 about here]

in settings where the benefits of management actions are delayed. Consider the Boeing Company, where the effects of management actions to land a large order for new aircraft may not appear in sales, earnings or EVA for as long as five or ten years. For this reason, Boeing employs one of a class of forward-looking metrics based on projected cash flows. Other industries where the effects of current actions can be seriously delayed include biotechnology, internet, software development, and wireless communications. Stern Stewart has proposed a solution to this problem in an article called "EVA For The Oil and Gas Industry," Journal of Applied Corporate Finance, Vol. 11, No. 3. (Fall 1998), 109-131.

${ }^{24}$ James S. Wallace, "Adopting Residual-Income-Based Compensation Plans: Do You Get What You Pay For?," Journal of Accounting \& Economics, Vol. 24, No. 3 (December 1997), 275-300. 
Operating decisions that use invested capital more efficiently will boost NOPAT and ROA, and other things equal, increase RI. For this reason, we would expect actions consistent with residual income incentives to increase asset turnover measured by sales over total assets: ${ }^{25}$

Q4: Does asset turnover increase for firms adopting residual income-based compensation plans (relative to non-adopters)?

As shown in Figure 5, total asset turnover increased by an average of 14 percent for firms adopting residual income relative to control firms in the period subsequent to adoption. This increase is statistically significant at conventional levels.

Investing decisions also boost RI to the extent they re-allocate capital away from activities that earn less than their capital costs and toward activities that earn more. If the adoption of a RI-based compensation plan simultaneously introduces greater awareness of the higher hurdle rate for investments (now explicit in the full weighted average cost of capital, WACC), other things equal we should observe increased asset divestitures and decreased new investments:

Q5: Do asset dispositions increase and asset acquisitions decrease for firms adopting residual income-based compensation plans (relative to non-adopters)?

As depicted in Figure 5, asset dispositions increased 100 percent and new investment decreased 21 percent after adoption (compared to pre-adoption levels) for the residual-income firms relative to the control firms. It is important to note that each of these results is driven by actions in the post-adoption period. In fact, the residual income adopting firms actually were

\footnotetext{
${ }^{25}$ For example, after adopting EVA, a large west coast manufacturing firm realized that, while its purchasing group had incentives to cut costs (and thus the input price of component parts), they had little incentive to control the level of parts inventory. Senior management quickly decided that it was more effective to cut inventory (and thus Capital) than to minimize price. As a consequence they moved a large amount of their purchases to wholesalers instead of buying directly from manufacturers who imposed higher order minimums and inflexible delivery schedules. Allegedly, this firm was willingly to pay up to $15 \%$ more than past prices to achieve lower target inventory levels.
} 
investing more relative to the control firms in the pre-adoption period. Each of these changes is significant at conventional levels. However, it is difficult to interpret whether an observed reduction in net investment is a value-increasing action since it is possible that managers are reducing positive NPV projects - not just projects earning below their cost of capital. Critics of RI-based compensation plans claim that they provide incentives for managers to under-invest in positive NPV projects. Proponents and users of RI-based incentives claim otherwise. ${ }^{26}$

Financing decisions also should be influenced by the adoption of RI-based incentives.

Given that holding capital that earns less than WACC penalizes RI, we expect to observe increased payouts to shareholders. If these payouts reflect discrete one-time responses to new RI-based compensation incentives and tax incentives, we are more likely to see an increase in share repurchases than in regular cash dividends: $:^{27}$

Q6: Do share repurchases and dividend payouts increase for firms adopting residual income-based compensation plans (relative to non-adopters)?

As shown in Figure 5, both repurchases per share and dividends per share increase in the postadoption period relative to the pre-adoption period. Relative to the matched-pair control firms, residual income adopters on average dramatically increased repurchases per share $(\$ 1.09$ or $112 \%$ ) but only slightly increased dividends per share $(\$ 0.13$ or $1 \%)$. Only repurchases per share are significant at conventional levels. These findings suggest that managers faced with higher investment hurdle rates under RI return excess capital to shareholders in a tax-favored manner that does not signal a permanent change in dividend payout.

\footnotetext{
${ }^{26}$ If their pay or prospects are tied to periodic accounting performance, managers may avoid positive NPV projects that are slow to pay off. It has been argued that RI, because it tends to apply a higher investment hurdle rate of return, will exacerbate this tendency. Perhaps one of the most vocal critics is the consulting firm Boston Consulting Group. See, for example, Eric Olsen in the October 1996 Boston Consulting Group publication, Perspectives. For a rebuttal, see John Shiely, COO of Briggs and Stratton, an EVA firm. Mr. Shiely's response was published in the February 1997 Stern Stewart publication, EVANGELIST ${ }^{\mathrm{T}}$.
} 
Finally, if managers take actions consistent with RI incentives, firms that adopt RI incentives should produce increased residual income:

Q7: Does residual income increase for firms adopting residual income-based compensation plans (relative to non-adopters)?

Here the evidence reveals that following adoption of RI-based incentive plans, the RI firms relative to the control firms increased residual income by a statistically significant average of nearly \$190 million annually (almost 1300\%). This result is consistent with the adage that you get what you measure and reward.

Although these results suggest that the adoption of residual income based incentives alter management decisions in ways that should contribute to shareholder wealth, several caveats are in order. First, firms that adopt new incentive plans may simultaneously change other aspects of their operations that also could influence management decisions (e.g., management realignments, strategic repositionings, restructurings, etc.). Thus, observed changes in management behavior could be due at least in part to these other effects. Second, our sample is not random since firms choose voluntarily to adopt residual income-based plans. It could be, for example, that managers opt for residual income based compensation when they forecast success unrelated to the incentives in the plan. ${ }^{28}$ Finally, one should be careful not to interpret these results strictly as confirming shareholder value creation. While they suggest changes in management behaviors that are consistent with RI incentives, it remains for future research to confirm that resulting benefits have been realized by shareholders.

\footnotetext{
${ }^{27}$ Share repurchases are tax favored over dividends in two respects - they are taxed at a lower rate for many taxpayers and taxpayers can choose whether to receive and thus be taxed on them.

${ }^{28}$ See, for example, Chris Hogan and Craig Lewis, "The Long-Run Performance of Firms Adopting Compensation Plans Based on Economic Profits," working paper, Vanderbilt University (1999), who argue that managers adopt RI-based plans opportunistically in anticipation of increased profitability and that adopting firms do not significantly outperform peer companies in creating shareholder wealth.
} 


\section{DISCUSSION AND SUMMARY}

The introduction of EVA and competing performance metrics can rightly be regarded as one of the most significant management innovations of the past decade. As key components of the shareholder value movement, they have stimulated both management interest and academic research. A variant of the long-appreciated concept of residual income, EVA is well understood to provide desirable management incentives under appropriate conditions. Less self-evident are two key claims that have been made regarding EVA as part of a heated competition that has emerged among metrics providers. These are that EVA better explains stock returns and firm values than traditional accounting earnings and that EVA better motivates managers to increase shareholder wealth. This article provides evidence from recent independent research regarding these claims.

Regarding the first claim that EVA is more closely associated with stock returns and firm value than is net income, independent research suggests that EVA does not dominate traditional accounting earnings in associations with stock returns and firm values. On the contrary, the evidence suggests that earnings generally beats EVA in value relevance to market participants. One possible explanation is that Stern Stewart's proprietary adjustments of GAAP earnings "undo" informative accounting accruals (e.g., bad debts and deferred taxes). Another possibility is that EVA and residual income contain little news beyond that already conveyed by earnings. If net income disclosures, for example, convey news regarding unexpected revenues and costs, and the market provides its own cost of capital estimate, there may be little news left to glean from EVA and residual income. Alternatively, market participants may apply a different set of adjustments than those provided by Stern Stewart (e.g., different amortization periods for 
capitalized marketing and R\&D costs). It also is possible that, for time periods studied, market participants had yet to recognize the information contained in EVA and residual income.

Regarding the second claim that EVA and residual income better motivate managers to increase shareholder wealth, independent evidence suggests that firms that adopt residual incomebased incentives tend to a) improve operating efficiency by increasing asset turnover, b) dispose of selected assets and reduce new investment (which adds value provided these assets were failing to earn adequate returns when compared to the firm's overall cost of capital), and c) repurchase more shares (consistent with distributing underperforming capital to shareholders). Firms that adopt RI incentive plans also exhibit increased residual income, confirming the adage that you get what you measure and reward. These findings support a pre-condition for shareholder wealth creation by confirming that managers respond to residual income-based incentives.

At this point a reader might ask how these results can be reconciled. Is it possible that residual income-based incentives can motivate managers to take actions consistent with shareholder wealth creation when earnings beats EVA and residual income in associations with stock returns and firm values? We believe so. As argued by Jerold Zimmerman in a previous edition of this journal, these issues are separable. ${ }^{29}$ As Zimmerman puts it,

"The success of a given performance measure in tracking near-term changes in a company's stock price is unlikely to be the most important consideration in choosing a measure as a basis for managerial rewards.” (p. 107) “And the best performance measure is the one that, without imposing excessive costs, gives managers the strongest incentives to take actions that increase firm value." ( $p$. 106)

Thus, it is possible for a metric to be quite useful for internal incentive purposes even though it conveys little if any news to market participants regarding the firm's future prospects. Similarly, 
a measure that is useful to capital market participants for determining share prices is not necessary useful as a management incentive tool. Therefore, EVA and residual income could prove effective in motivating shareholder wealth creation without being informative to investors, and claims linking the two should be interpreted with care. Ultimately, if an internal metric or compensation plan more effectively motivates shareholder wealth creation, shareholders should benefit regardless of its correlation with stock returns and firm values. Whether implementations of EVA and residual income-based incentives have been truly effective in this regard remain an open question for further research.

Gary Biddle holds a joint appointment at the University of Washington Business School and at the School of Business Management of Hong Kong University of Science \& Technology where he is professor and head of the department of accounting.

Robert Bowen is the Herbert O. Whitten Professor of Accounting at the University of Washington Business School.

James Wallace is an Assistant Professor of Accounting at the Graduate School of Management, University of California at Irvine.

\footnotetext{
${ }^{29}$ Jerold L. Zimmerman, "EVA and Divisional Performance Measurement: Capturing Synergies and Other Issues," Journal of Applied Corporate Finance, Vol. 10, No. 2 (1997), 98-109.
} 


\section{FIGURE 1}

\section{RECONCILING OPERATING CASH FLOWS, EARNINGS, OPERATING PROFITS, RESIDUAL INCOME AND ECONOMIC VALUE ADDED ${ }^{*}$}

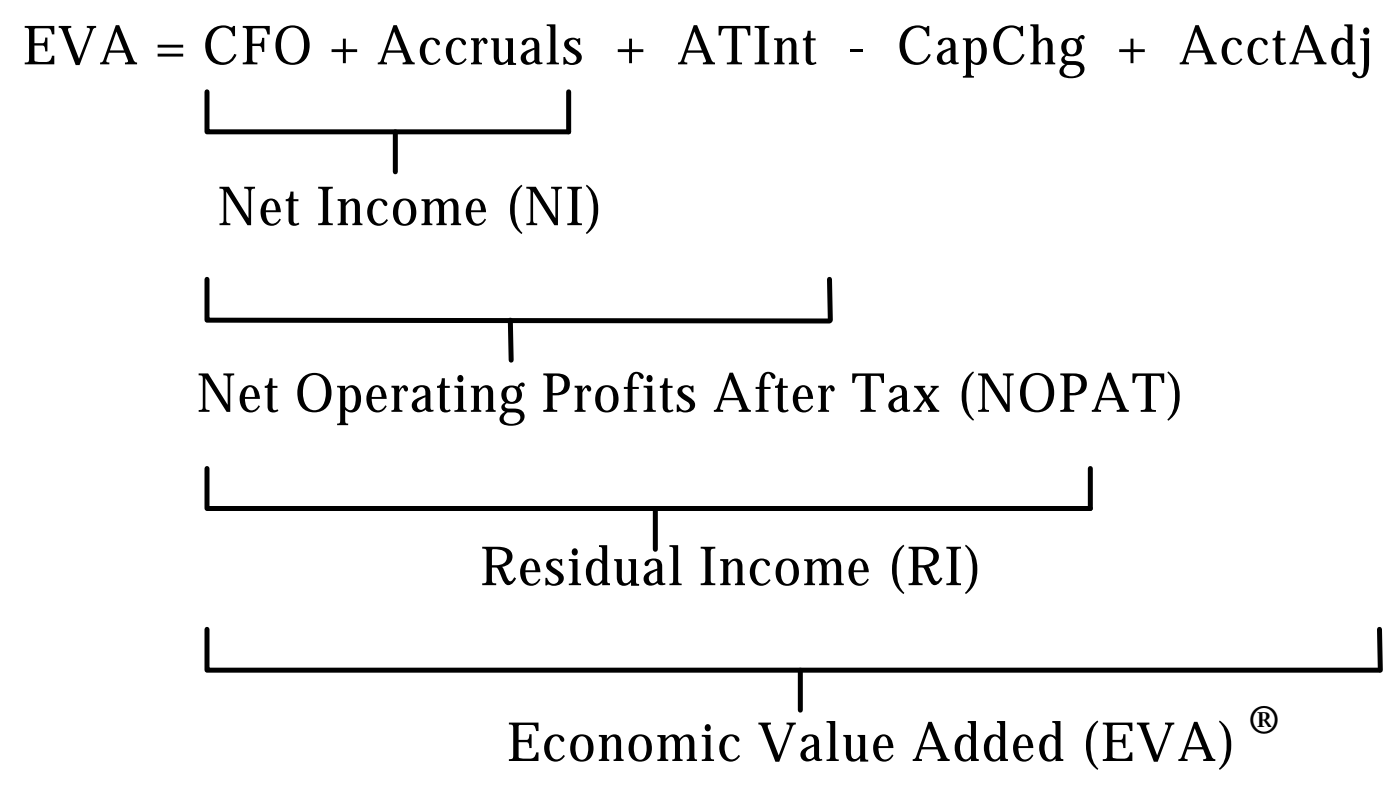

* This figure shows the relation between cash from operations, accounting earnings, residual income, and economic value added. Definitions of each component are below:

- $\quad \mathrm{CFO}=$ cash flow from operations

- $\quad$ Accruals $=$ accruals introduced by the financial accounting process

- $\quad \mathrm{NI}=$ net income before extraordinary items

- $\quad$ ATInt $=$ after-tax interest (added back to produce an operating performance number that is before the cost of financing)

- $\quad$ NOPAT $=$ net operating profits after tax (not to confused with Stern Stewart's NOPAT that includes adjustments to accounting earnings and capital)

- CapChg = charge for the estimated current cost of debt and equity capital

- $\quad$ AcctAdj = Stern Stewart's adjustments to NOPAT and Capital for alleged accounting distortions

- $\quad \mathrm{EVA}^{\circledR}=$ economic value added (registered tradename of Stern Stewart \& Company) 
FIGURE 2

MEDIAN VALUES OF PERFORMANCE MEASURES, 1988-97 (in millions)*

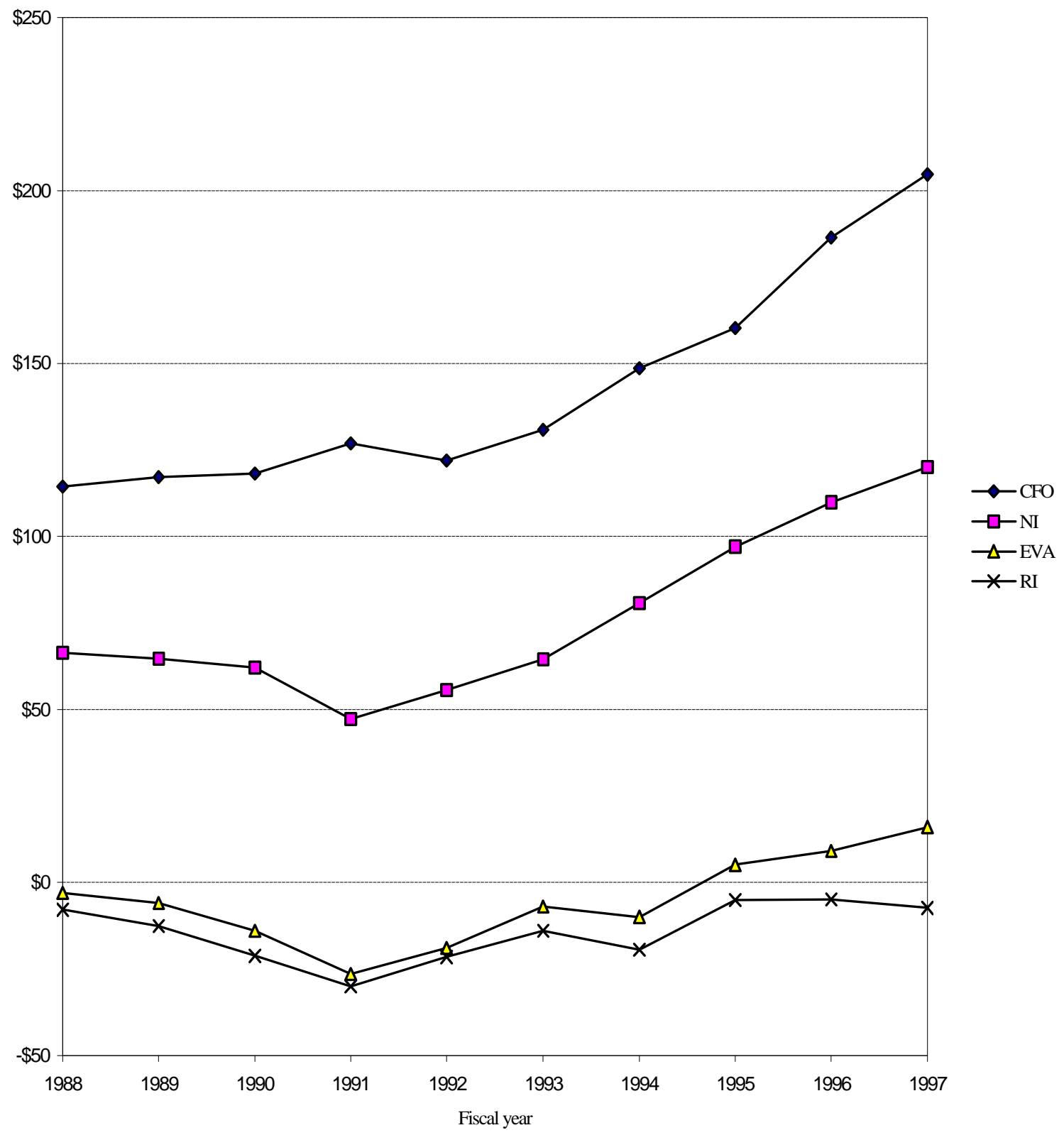

* Median values of cash from operating activities (CFO), net income before extraordinary items (NI), economic value added (EVA) and residual income (RI) for the period 1988-97. Data source: Stern Stewart and Company and Standard \& Poors' COMPUSTAT. 


\section{FIGURE 3}

RELATIVE INFORMATION CONTENT OF EVA ${ }^{\circledR}$, RESIDUAL INCOME, EARNINGS AND OPERATING CASH FLOW* ${ }^{*}$ (TEST OF QUESTION 1)

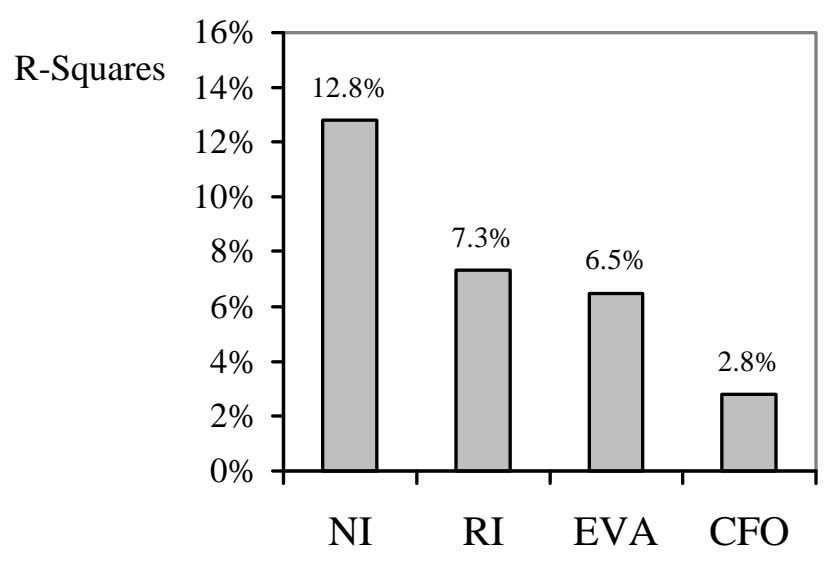

* Bar heights show relative information content comparisons based on goodness of fit (adjusted $\mathrm{R}^{2}$ ). For details see Biddle, Bowen and Wallace (1997), cited above. 
FIGURE 4

\section{ASSOCIATIONS BETWEEN CONTEMPORANEOUS STOCK RETURNS AND

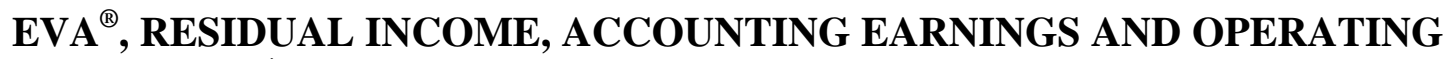 CASH FLOW* (TESTS OF QUESTIONS 1-2)}

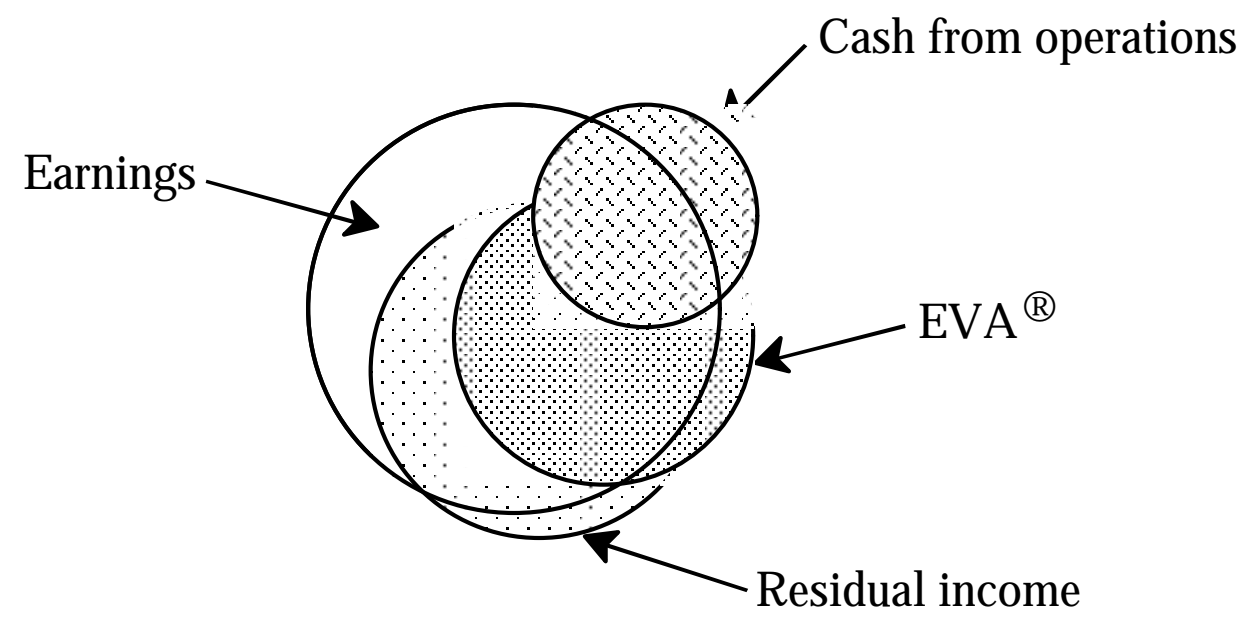

* This figure combines relative information content comparisons (Adjusted $\mathrm{R}^{2} \mathrm{~s}$ ) for question 1 , shown as circle sizes, and incremental information content comparisons (F-statistics) for question 2, shown as relative positioning or lack of overlap (with less overlap indicating more incremental information content). For details see Biddle, Bowen and Wallace (1997), cited above. 
FIGURE 5

INCENTIVE EFFECTS FOLLOWING ADOPTION OF RESIDUAL INCOME BASED COMPENSATION PLANS* (TESTS OF QUESTIONS 4-6)

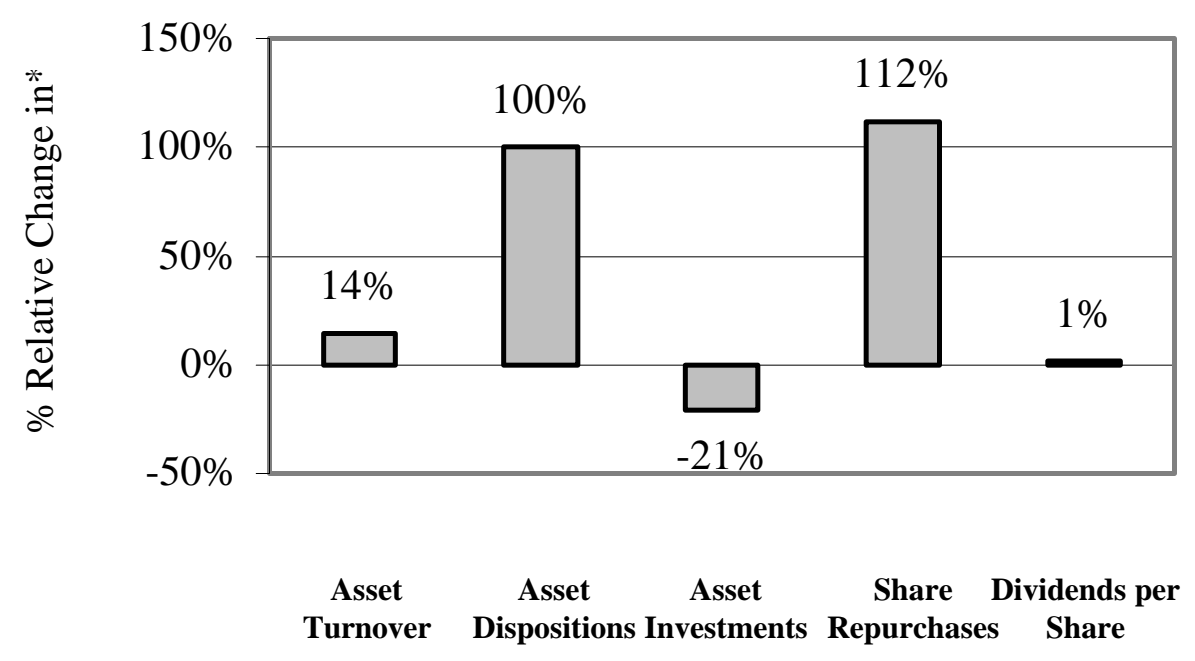

\footnotetext{
* Percentage changes in selected actions of firms that adopt residual income based compensation plans (relative to a control group of non-adopters). For example, asset turnover increased $14 \%$ relative to a control group when compared to the pre-adoption period. More specifically, the percentage change in 'asset turns' equals the average asset turnover for the treatment (adopter) group $(=1.24)$ less the average asset turnover for the control (non-adopter) group $(=1.08)$, with this difference scaled by the average asset turnover for both groups in the period before adopting RI based compensation plans $(=1.125)$. In numbers, $(1.24-1.08) / 1.125=.14$ or a $14 \%$ relative increase in asset turnover subsequent to adoption of residual income based plans. For more details on these results, see Wallace (1997), cited above.
} 
TABLE 1

EXAMPLES OF TYPICAL STERN STEWART ADJUSTMENTS FOR ALLEGED ACCOUNTING DISTORTIONS

\section{Common Areas where GAAP- based Accounting is Adjusted*}

Marketing and R\&D costs

Deferred taxes

Purchased goodwill

Operating leases

Bad debts and warranty costs

LIFO inventory costing

Construction in progress

Discontinued operations

\author{
GAAP Treatment Nature of Adjustments ${ }^{* *}$ \\ Expense \\ Record as asset and amortize \\ Record as asset \\ Reverse recording of asset \\ and/or liability \\ and/or liability to reflect cash \\ basis reporting
}

Record as asset; Reverse amortization to reflect amortize over up original asset amount

to 40 years

Expense

Record asset and amortize; record liability and related interest

Estimate accrual

Reverse accruals to reflect cash basis reporting

LIFO permitted

Convert to FIFO

Record as asset

Remove from assets

Include in assets

and earnings
Remove from assets and earnings

\footnotetext{
* Common examples of Stern Stewart's adjustments. For example, the effect of capitalizing R\&D is to add to CAPITAL (assets) past R\&D expenses, less accumulated amortization. The effect on NOPAT (earnings) is to add back current $R \& D$ expenses and subtract the period's amortization of capitalized R\&D. For a firm experiencing growth (decline) in $\mathrm{R} \& \mathrm{D}$, the adjustment increases (reduces) contemporaneous NOPAT. The effect on EVA depends on the amount of capitalized R\&D. For a firm in steady state, the adjustment has little net effect on NOPAT, but increases CAPITAL, thereby reducing EVA.

** Stern Stewart's rationales for these adjustments include: a) to better represent the underlying economics of the transactions; b) to reduce incentives for dysfunctional or suboptimal decision making; and c) to improve comparability externally (across firms) and internally (e.g., across divisions) by putting the accounting on a similar basis. Not all rationales apply to each adjustment.
} 
Filename: $\quad 178168$

Directory: $\quad$ C:IWINDOWSIDESKTOP

Template: $\quad$ Normal.dot

Title: $\quad$ EVAdence on EVA®

Subject:

Author: $\quad$ CCST

Keywords:

Comments:

Creation Date: $\quad$ 08/27/99 9:31 AM

Change Number: 2

Last Saved On: $\quad$ 08/27/99 9:31 AM

Last Saved By: Jim Wallace

Total Editing Time: 4 Minutes

Last Printed On: $\quad$ 09/09/99 5:05 PM

As of Last Complete Printing

Number of Pages: 26

Number of Words: $\quad$ 5,322 (approx.)

Number of Characters: $\quad 30,340$ (approx.) 